\title{
THE IMPACT OF MONEY ON OUTPUT IN CZECH REPUBLIC AND ROMANIA
}

\author{
Mihaela SIMIONESCU ${ }^{1}$, Adam P. BALCERZAK ${ }^{2}$, Yuriy BILAN ${ }^{3^{*}}$ (D), \\ Anna KOTÁSKOVÁ 4 \\ ${ }^{1}$ Institute for Economic Forecasting, Bucharest, Romania \\ ${ }^{2}$ Department of Economics, Nicolaus Copernicus University, Toruń, Poland \\ ${ }^{3}$ Faculty of Management and Economics, Centre of Applied Economic Research, \\ Tomas Bata University in Zlin, Zlín, Czech Republic \\ ${ }^{4}$ Faculty of Economics and Business, Paneuropean University in Bratislava, \\ Bratislava, Slovakia
}

Received 29 November 2017; accepted 23 February 2018

\begin{abstract}
The problem of relationship between output and money has become again a subject of special interests of economists after the most recent global financial crisis and monetary stabilization policies applied by central banks of almost all developed economies. In this context, the main aim of this paper is to assess the relation between GDP and the most important monetary variables in two countries: Romania and Czech Republic over the period of 1995:Q1 - 2015:Q4. The choice of these economies was deliberate. The selected countries are different from the viewpoint of rate and results of transformation from the centrally planned to market economy, which have influenced their current economic environment stability. Czech Republic is currently classified as middle or even developed country, whereas Romania is still considered as a developing economy. Thus, differences between these two countries make them interesting in the case of comparative studies. In the empirical part of our research the vector error correction models (VECM) were applied. The main findings of the article are the following: in Romania, there is a short-run causality from money supply (M3) to GDP and a long-run relationship between GDP, internal credit and M3. According to Granger causality test, the rate of M3 in Romania was a cause for economic. In Czech Republic, there is a short-run causality from M3 to GDP and a long-run causality between GDP, internal credit and M3. Thus, the results contradict the money neutrality hypothesis in post-transformation Central European economies.
\end{abstract}

Keywords: GDP, VECM, internal credit, money supply, money demand, neutrality of money, Granger causality.

JEL Classification: C11, C13, C51.

${ }^{\star}$ Corresponding author. E-mail: yuriy_bilan@yahoo.co.uk 


\section{Introduction}

The debate concerning the effectiveness of monetary policy and its influence on short- and long-term growth has been present in the core of modern macroeconomics since its beginning starting from the publication of The General Theory of Employment, Interest and Money. The importance and actuality of this topic is related to the construction of sustainable monetary policy, which is the condition for ensuring healthy economic growth. Thus, both academic economists and policymakers have been interested in measuring the potential influence of monetary variables on output. The issue has been the subject of intensive research in literature (starting with Sims 1972; Stock, Watson 1989; King, Watson 1997). Since the end of 1980 till the beginning of 2000s, the role of money was overlooked in a large number of studies (Taylor 1999; Clarida et al. 2000).

At the end of the previous century it seemed there was a commonly accepted consensus concerning the concept of middle- and long-term neutrality of money. There could be also seen a strong skepticism as to application of monetary tools for the objectives of short-term stabilization. It was commonly believed that central banks should only concentrate on the inflation stabilization purposes. From the policy guidelines perspective, it could be seen, for example, in the Maastricht treaty criteria or the suggested good governance practices related to first Washington consensus. However, monetary stabilization actions conducted in the United States after 2000 have contributed to the renewal of research interests in the relation between monetary policy tools and output (see Belongia, Ireland 2016). As a result, currently many economists suggest that money can be still a strong policy instrument during an economic crisis (Nelson 2003; Duca, Van Hoose 2004; Sims, Zha 2006; Hill 2007; Yıldırım 2015). The research topic has also gained special actuality after the latest global financial crisis and the related large-scale monetary stabilization policies applied by almost all developed and many developing economies as well (Janus 2016; Jędrzejowska-Schiffauer, Schiffauer 2016; Palankai 2015; Svitálková 2014).

In this context, the main aim of this paper is to analyze the relationship between output and monetary variables using some econometric approaches (Granger causality on stationary data, vector error correction models, dynamic panel data models). The research was conducted for Czech Republic and Romania for the years 1995:Q1 - 2015:Q4. We selected these countries deliberately based on their comparative value from the perspective of comparative studies in Central European post-transformation economies concerning the effectiveness of monetary policy tools in different institutional and macroeconomic environment (Lakic et al. 2015). The countries have had different paths in their economic development after 1990. Czech Republic succeeded in making quick transition to the market economy, while Romania still faces problems in getting a sustainable economic growth. Czech Republic is currently the most developed Central European economy; it is also a member of OECD, whereas Romania is still considered as a developing economy. Thus, this makes these two countries an interesting case study from the comparative perspective. It is important to see in these two types of economies if there are still differences regarding the money-output relationship.

This contribution can be placed into the current empirical research context concerning the concept of money neutrality in case of the economies being at different development levels. The key novelty of our research is the approach based on time series to study long-run 
and short-run relationship completed by a panel data approach based on dynamic panel models for the two post-transformation countries. Moreover, this study is not reduced to causality analysis, estimations being provided for each country.

In the next section, review of the previous empirical literature concerning highly developed and developing countries is provided. Then the methodology used in the empirical research is briefly described. The results of econometric estimations are presented in the next part, while the last section concludes.

\section{Review of previous empirical research for highly developed and developing economies}

New approaches from literature have currently focused on the money-output causality in the light of complex methods. Starting with the developed economies the money-output causality for the United States in the years 1959-2006 was verified by Gefang, who was using the logistic smooth transition vector error correction model (Gefang 2012). In the postwar period, a nonlinear relationship between money and output was detected, the changes being due to price levels and increases in output. In the traditional approach, money was not a Granger cause for output. Only a nonlinear causality between money and GDP was identified.

Long-run neutrality of money in the United States in the years 1959-2009 was tested by Lee, who applied a nonparametric testing procedure based on spectral approaches for analyzing relation between nominal money and real output (Lee 2012). In his approach long-run effects between bivariate integrated series were represented as the spectral density matrix of their first-differences evaluated at the zero frequency. The long-run neutrality was reduced to zero power of the cross spectral density function near the origin. The applied procedure enabled to reject the long-run neutrality for M2.

Quite similar results were obtained by Li et al., who performed some empirical tests for Granger causality between U.S. money and output and between the return and volume of the CSI 300 Index in the years 1959-2014 (Lee et al. 2016). They applied the generalized crossspectral distribution function, which enabled to prove that the test statistic captured the nonlinear Granger causality. On the other hand, Albuquerque et al. used a Bayesian approach to study the Granger causality between money and GDP growth in the US (Albuquerque et al. 2016). The Great Moderation was characterized by strong causality from money to economic growth in the period 1960-2005. After 2005 money had no influence on output growth.

In the case of United States and the debate concerning the concept of money neutrality interesting results were obtained (Sargent, Surico 2011) who showed the instability of lowfrequency regression coefficients that Lucas (1980) used to express the quantity theory of money. The authors extended the Lucas analysis (1955-1975) to a long period of 1900-2005. In their research a DSGE model estimated over a subsample like Lucas's implied values of the regression coefficients that confirm Lucas's results. However, perturbing monetary policy rule parameters away from the values estimated over Lucas's subsample alters the regression coefficients in ways that reproduce their instability over longer sample. Thus, the authors were able to document periods in which the quantity theory of money propositions broke down and identified alterations in monetary policies that can account for those breakdowns. 
Moving to international experience Bae et al. used a bivariate, fractionally integrated, autoregressive, moving average (ARFIMA) model of money and real output to extend Fisher and Seater's long-run neutrality and superneutrality in an ARIMA framework (Bae et al. 2005). The research was based on time series for a century of low frequency income and money supply data for Argentina (1884-2001), Canada (1880-2001), Italy (1880-1998), Sweden (1880-1995), the United Kingdom (1880-2001), and the United States (1880-2001). The authors confirmed long-run neutrality in every country except Sweden. On the other hand, form the policy perspective, they found that even when money has no lasting long-run impact on real output, positive monetary shocks tended to have a significant and persistent positive effect on the level of output.

Chen investigated the long-run money neutrality with application of data for South Korea (1970-2004) and Taiwan (1965-2004), where a special attention was given to the integration and cointegration properties of the variables (Chen 2007). The research supported the long-run neutrality of money with respect to real output for South Korea. However, in the case of Taiwan, there was no evidence that could support the long-run monetary neutrality for Taiwan. Additionally, based on his estimations the short-run neutrality of money was rejected for both economies.

An interesting comparative study for developed and developing economies was proposed by Issaoui et al., who applied a structural vector error correction (SVEC) model to a comparative research on the United States, Morocco and Gabon for the years 19602011 in the case of the US and Morocco, and 1962-2011 for Gabon (Issaoui et al. 2015). They examined the long-term relationship among money supply (M2), income (GDP), and prices (CPI). They showed noticeable differences between developed and developing economies, as they confirmed the long-term non-neutrality of money supply in the United States, and its neutrality in Gabon and Morocco. Their results showed that the short-term effect of a monetary shock on GDP is positive and decreasing, which can be treated as a confirmation of the Keynesian approach, according to which money positively affects output. In the case of the long-term, the effects of the shocks were not systematically zero. They showed that it was zero in Gabon while positive, decreasing, and at lower rates in Morocco and the USA.

Concentrating strictly on the developing countries Wang et al. analyzed the time-varying causal dynamics in the case of China's money and output based on Markov switching causality approach (Wang et al. 2014). The advantage of this approach is that the Markov switching causality method might capture the time-varying causality patterns in an endogenous way. The results indicated that there was a bidirectional time-varying Granger causality between money and output in China.

Saatcioglu and Korap investigated validity of the quantity theory of money relationship for Turkish economy in the years 1950-2006 with application of some contemporaneous time series estimation techniques (Saatcioglu, Korap 2009). They found that there exists an about one-to-one proportionality between money and prices and money and real income, and that erogeneity of money cannot be rejected for the currency in circulation in the economy. However, in the case of the broad monetary aggregate money seemed to be endogenous as for the long-term variable space. 
Asongu analyzed the long-and short-run effects of monetary policy on economic activity (output and prices) in the CEMAC and UEMOA CFA franc zones with application of VARs within the frameworks of Vector Error-Correction Models and Granger causality models (Asongu 2016). Based on the research a hypothesis that monetary policy variables affect prices in the long-run but not in the short-run in the CFA zones was rejected. In regard to the influence of monetary variables on output he confirmed the neutrality of money in the long term. On the other hand, in the short-run with the exception of overall money supply, the significant effect of money on output was more relevant in the UEMOA zone, than in the CEMAC zone, where only financial system efficiency and financial activity were significant.

Telatar and Cavusoglu investigated the hypothesis of long-run neutrality and long-run superneutrality of money in the second half of XX century for high inflation countries: Argentina, Brazil, Ecuador, Mexico, Uruguay and Turkey (Telatar, Cavusoglu 2005). They applied Fisher and Seater's bivariate ARIMA representation where money and real output are modeled with log-linear system (Fisher, Seater 1993). Their final results were country specific as money was long-run neutral but not superneutral with respect to real output for Argentina and Uruguay. In these countries money growth had a negative effect on real output. The long-run superneutrality was confirmed for Brazil, Mexico and Turkey. On the other hand, the long-run neutrality was rejected for Ecuador.

Moreover, Hiscock and Handa concentrated on testing long-run money neutrality and superneutrality for all South American economies for the years 1960-2009 (see Hiscock, Handa 2013). By analogy to previous research they applied Fisher and Seater's procedure and they used M1 and M2 as monetary variables. In their research money neutrality was not rejected for Brazil, Chile, Colombia, Guyana, Suriname, Uruguay and Venezuela. However, it was rejected for Argentina, Bolivia, Ecuador, Paraguay and Peru. In the case of the countries, where superneutrality could be tested, it was not rejected for Bolivia, Brazil, Chile, Colombia, Guyana, and Uruguay. It was rejected for Argentina and Peru.

For Czech Republic, a vector autoregression approach was implemented to support the relationships between output and few macroeconomic variables. The causality approach suggested that past price evolution is a Granger cause for interest rate, previous evolution of GDP influences the interest rate while past real GDP causes variations in price level (Urbanovský 2016).

For Romania and Slovak Republic, a Bayesian approach put into evidence the negative impact of internal credit on output growth in the period 1995-2016 (Korauš et al. 2017). This negative correlation might be explained by the changes brought by the global economic crisis. For Romania, the empirical findings for the relationship between GDP and monetary variables showed that there was a bidirectional relation between changes in real money demand and output growth in the period 2000-2015, using data with quarterly frequency (Simionescu et al. 2017).

The presented review of empirical literature confirms that the research on the relation between monetary variables and output is still in the center of interests of economists. What is more, the provided literature review confirms important differences in the final results depending on the economy and its stage of development, analyzed period and applied methodological approach. 


\section{Methodology}

The stationarity of a time series is an essential characteristic, because it might affect its behaviour. If the data series for $x$ and $y$ are non-stationary and random processes (integrated series), when modelling the relationship between $\mathrm{x}$ and $\mathrm{y}$, the use of a simple OLS could determine a spurious (false) regression. By definition, the stationary of a time series is a statistical property that implies constant mean and variance over time.

If the data series is stationary without differencing it, then the data series is integrated of order $0(\mathrm{I}(0))$. If the data set is stationary in the first difference, then it is integrated of order $1(\mathrm{I}(1))$. Augmented Dickey-Fuller or Phillips-Perron test might be used to test for the stationary character of the data series.

According to Simionescu, the number of cointegrated vectors could be determined using Johansen and Juselius cointegration test: trace test or maximum eigenvalue test (Simonescu 2014). The last test considers a null hypothesis that states that there are $r$ cointegrating relations, while the alternative assumption considers $r+1$ cointegrating relationships when $r=0,1,2, \ldots, n-1$. The test statistics has the following form:

$$
L R_{\max }\left(\frac{r}{n}+1\right)=-T \log (1-\widehat{\lambda)},
$$

where $\lambda$ - maximum eigenvalue, $T$ - sample size, $n, r$ - number of cointegrating relationships, $L R_{\max }-$ maximum likelihood ratio.

Trace statistics test considers a null hypothesis that states that there are $r$ cointegrating relations, while the alternative assumption considers $n$ cointegrating relationships when $r=0$, $1,2, \ldots, n-1$. The test statistics has the following form:

$$
L R_{t r}\left(\frac{r}{n}\right)=-T \sum_{i=r+1}^{n} \log \left(1-\widehat{\lambda_{i}}\right),
$$

where $\lambda$ - maximum eigenvalue, $T$ - sample size, $n, r$ - cointegrating relationships, $L R_{\max }-$ trace likelihood ratio.

In practice, there are cases when maximum eigenvalue and trace statistics indicate different results, but always the result based on trace test should be preferred (see Fałdziński et al. 2016; Pietrzak et al. 2017).

If a cointegration relationship has been identified, then there is a long-run equilibrium relationship between the variables. The vector error correction model (VECM) is estimated in order to assess the short-run characteristics of the co-integrated series. In case of no cointegrated relationship, the VECM is not estimated and Granger causality is checked on stationary data series. For the VECM we have the following regression equations:

$$
\begin{gathered}
\Delta Y_{t}=\alpha_{1}+p_{1} e_{1}+\sum_{i=0}^{n} \beta_{i} \Delta Y_{t-i}+\sum_{i=0}^{n} \delta_{i} \Delta X_{t-i}+\sum_{i=0}^{n} \gamma_{i} Z_{t-i} ; \\
\Delta X_{t}=\alpha_{2}+p_{2} e_{2}+\sum_{i=0}^{n} \beta_{i}^{\prime} \Delta Y_{t-i}+\sum_{i=0}^{n} \delta_{i}^{\prime} \Delta X_{t-i}+\sum_{i=0}^{n} \gamma_{i}^{\prime} Z_{t-i},
\end{gathered}
$$

where $Y_{t-i}, X_{t-i}, Z_{t-i}$ - variables with lag $i, \Delta Y_{t}, \Delta X_{t}$ - variables $Y$ and $X$ in first difference, $\alpha_{1}, \alpha_{2}$-intercepts, $e_{1}, e_{2}$ - error terms, $p_{1}, p_{2}, \beta_{i}, \beta_{i}^{\prime}, \delta_{i}, \delta_{i}^{\prime}, \gamma_{i}, \gamma_{i}^{\prime}$ - coefficients. 
The cointegration rank in the VECM framework indicates the number of cointegrating vectors. A significant and negative coefficient for VECM shows that the short-run fluctuations between the dependent variable and the explanatory ones determine a stable long-term relationship between variables.

We can describe the Granger causality between two variables $X$ and $Y$ as:

$$
\begin{gathered}
Y_{i}=\alpha_{0}+\alpha_{1} Y_{t-i}+\ldots+\alpha_{i} Y_{t-i}+\beta_{1} X_{t-1}+\ldots+\beta_{i} X_{t-i}+\mu \\
\mathrm{X}_{\mathrm{t}}=X_{i}=\alpha_{0}^{\prime}+\alpha_{1}^{\prime} X_{t-i}+\ldots+\alpha_{i}^{\prime} X_{t-i}+\beta_{1}^{\prime} Y_{t-1}+\ldots+\beta_{i}^{\prime} Y_{t-i}+\mu^{\prime},
\end{gathered}
$$

where $X_{t}, Y_{t}$ - variables $X$ and $Y$ at time $t, \alpha_{0}, \alpha_{1}, \ldots, \alpha_{i}, \alpha_{0}^{\prime}, \alpha_{1}^{\prime}, \ldots, \alpha_{i}^{\prime}, \beta_{1}, \ldots, \beta_{i}, \beta_{1}^{\prime}, \ldots, \beta_{i}^{\prime}-$ coefficients, $\mu, \mu^{\prime}$ - errors term following a white noise. The subscript is used for time periods.

The trend in $X$ and $Y$ is seen as general movements of cointegration that appear between $X$ and $Y$ and it follows a unit root process. We can apply the test twice: to study if $X$ does not Granger cause $Y$ and to study if $Y$ does not Granger cause $X$. If the first null hypothesis is not rejected and the second one is rejected, then changes in $X$ are Granger caused by the modifications in $Y$. If the first null hypothesis is rejected and the second one is not rejected, then changes in $Y$ are Granger caused by the modifications in $X$. If both assumptions are rejected, then we have a bidirectional relationship between variables.

\section{Models for GDP in Romania and Czech Republic considering monetary explanatory variables}

The data of this research are related to the following macroeconomic variables for Czech Republic and Romania in the period 1995:Q1 - 2015:Q4: gross domestic product (GDP) at market prices (Chain linked volumes (2010), million Euro), Euro/RON, respectively Euro/ Koruna exchange rate $(E R)$, monetary policy interest rate, money demand $M 2$, money supply M3 (defined as liquid liabilities of the banking system), and domestic or internal credit. The Eurostat database is the source for GDP data series, the rest of the variables having data provided by the National Bank of the two states.

After the transformation disturbances in the early 90s, Romania has experienced a long period of economic growth, which was interrupted by two international crisis episodes: the international instability of the year 2001 and then the world economic and financial crisis in the last quarter of 2008. As a result, in the analyzed period the first significant shock in the Romanian economy occurred in the second quarter of 2001 because of the international context: the decrease in oil price and in the EU imports, the famous terrorist attacks in the $11^{\text {th }}$ of September 2001, less industrial production in the euro area. In Romania, the industrial production declined because of the capital market contraction in the first three quarters. However, these external threats did not decrease consumption and GDP. The signals of crisis were observed again in the middle of 2007, when the confidence indicator decreased in Romania and in the entire EU. Starting with the middle of 2008, generalized contractions in output were registered in the EU countries. Only in the last quarter of 2008, Romanian economy was declared to be in the recession period, while the foreign direct investment flow decreased since the beginning of 2009. The minimum value of GDP was registered in 
the third quarter of 2010. A recovery of labour market and GDP was observed starting with the end of 2010 .

Unlike Romania, the Czech Republic transformed relatively quickly to a market economy. The conservative monetary and fiscal policies created a stable macroeconomic environment. However, in 1997 and 1998, the Czech Republic registered a serious economic decline, which was a consequence of a financial crisis after a massive speculative attack on the Czech crown in May 1997 conducted by international investors. After a set of serious structural and institutional reforms that were forced by the recession, since 2003 the output has registered a constant increase. The positive trend was supported by the entry in the EU in 2004, which helped to increase competitive advantage of the Czech goods on the foreign markets.

As the data series have quarterly frequency, the data were seasonally adjusted using the Tramo-Seats method. The correlation matrix is built for the variables with seasonally adjusted data (see Table 1), GDP_SA, CREDIT_SA, M2_SA represent seasonally adjusted data series for GDP, internal credit, money demand.

Table 1. Correlation matrix of the variables for Romania (source: authors' calculations)

\begin{tabular}{|l|c|c|c|c|c|c|}
\hline & GDP_SA & CREDIT_SA & ER & INTEREST & M2_SA & M3 \\
\hline GDP_SA & 1.000000 & 0.584920 & 0.822936 & -0.928452 & 0.933749 & 0.900368 \\
\hline CREDIT_SA & 0.584920 & 1.000000 & 0.811584 & -0.600563 & 0.588593 & 0.472047 \\
\hline ER & 0.822936 & 0.811584 & 1.000000 & -0.907489 & 0.808384 & 0.706380 \\
\hline INTEREST & -0.928452 & -0.600563 & -0.907489 & 1.000000 & -0.889402 & -0.844829 \\
\hline M2_SA & 0.933749 & 0.588593 & 0.808384 & -0.889402 & 1.000000 & 0.970475 \\
\hline M3 & 0.900368 & 0.472047 & 0.706380 & -0.844829 & 0.970475 & 1.000000 \\
\hline
\end{tabular}

Table 1 presents correlation matrix of the variables for Romania. Based on the values of Pearson's coefficients of correlation, in Romania there is a very strong correlation between the following pairs of variables: GDP and monetary policy interest rate, M2 and GDP and $M 3$ and GDP. The negative connection between GDP and interest rate is in line with the economic theory, because a lower interest rate promotes investment that is just a part of the $G D P$. The increase in money supply will generate increase in GDP. In general, the credit expansion brings increases in GDP and other macroeconomic variables. The exchange rate affects the net export. A depreciation of the national currency will increase net export and, consequently, the GDP. In this particular case, the national currency depreciation stimulates the deposits' holders to keep the money in foreign currency. For Czech Republic, the correlation matrix is built in Table 2 .

Correlation matrix of the variables for Czech Republic is given in Table 2. In Czech Republic, a very strong correlation was observed between the following variables: GDP and $M 2, G D P$ and $M 3, G D P$ and internal credit, $M 3$ and internal credit, M2 and internal credit, $M 2$ and M3. GDP is well correlated with exchange rate (Euro-Koruna), but weakly correlated with monetary policy interest rate. Taking into account all these connections, we can state that GDP in the Czech Republic might be explained by M3, internal credit and Euro/Koruna exchange rate. 
Table 2. Correlation matrix of the variables for Czech Republic (source: authors' calculations)

\begin{tabular}{|l|c|c|c|c|c|c|}
\hline & GDP_SA & M2_SA & M3_SA & ER & INTEREST & CREDIT_SA \\
\hline GDP_SA & 1.000 .000 & 0.908422 & 0.919134 & -0.85315 & -0.46237 & 0.928727 \\
\hline M2_SA & 0.908422 & 1.000 .000 & 0.99939 & -0.77222 & -0.67428 & 0.991988 \\
\hline M3_SA & 0.919134 & 0.99939 & 1.000 .000 & -0.78173 & -0.66297 & 0.993541 \\
\hline ER & -0.85315 & -0.77222 & -0.78173 & 1.000 .000 & 0.2884 & -0.83909 \\
\hline INTEREST & -0.46237 & -0.67428 & -0.66297 & 0.2884 & 1.000 .000 & -0.60934 \\
\hline CREDIT_SA & 0.928727 & 0.991988 & 0.993541 & -0.83909 & -0.60934 & 1.000 .000 \\
\hline
\end{tabular}

The econometric model will relate GDP to $M 3$ and internal credit. Before estimating the models, the presence of unit roots in data will be checked using Phillips-Perron test (see Table 3).

For Czech Republic, the data series for the following variables are stationary at 5\% level of significance: GDP rate, GDP in first difference, internal credit in first difference, exchange rate in first difference, interest rate in first difference, $M 2$ in the second difference, $M 3$ in the first difference, $M 3$ rate.

For Romania, GDP, M3 and internal credit data series in first difference are stationary at $5 \%$ level of significance. These results indicated that the variables are co-integrated of order 1 . Moreover, the rates of GDP, M2, M3 and internal credit have stationary data series at $5 \%$ level of significance.

Table 3. Results of Phillips-Perron test for checking the presence of unit roots (source: authors' calculations)

\begin{tabular}{|c|c|c|c|c|c|}
\hline \multicolumn{3}{|c|}{ Romania } & \multicolumn{3}{|c|}{ Czech Republic } \\
\hline Data series & $\begin{array}{l}\text { Adjusted } \\
t \text { statistics }\end{array}$ & $\mathrm{p}$-value & Data series & $\begin{array}{l}\text { Adjusted } \\
t \text { statistics }\end{array}$ & $\mathrm{p}$-value \\
\hline \multirow{3}{*}{$\begin{array}{l}\text { GDP_SA in } \\
\text { level }\end{array}$} & -1.881876 & 0.6550 & \multirow{3}{*}{$\begin{array}{l}\text { GDP_SA in } \\
\text { level }\end{array}$} & -1.607592 & 0.5027 \\
\hline & 0.085280 & 0.9628 & & -1.575171 & 0.0663 \\
\hline & 2.682684 & 0.9981 & & 2.251389 & 0.9936 \\
\hline \multirow{3}{*}{$\begin{array}{l}\text { GDP_SA in } \\
\text { first difference }\end{array}$} & -6.434980 & 0.0000 & \multirow{3}{*}{$\begin{array}{l}\text { GDP_SA in } \\
\text { first difference }\end{array}$} & -4.925436 & 0.0010 \\
\hline & -6.389570 & 0.0000 & & -4.839528 & 0.0002 \\
\hline & -5.832015 & 0.0000 & & -3.985701 & 0.0001 \\
\hline \multirow{3}{*}{ GDP rate } & -9.968784 & 0.0000 & \multirow{3}{*}{ GDP rate } & -5.016107 & 0.0007 \\
\hline & -16.31503 & 0.0000 & & -4.796143 & 0.0002 \\
\hline & -15.86018 & 0.0001 & & -2.031178 & 0.0066 \\
\hline \multirow{3}{*}{ Internal credit } & -2.656990 & 0.2571 & \multirow{3}{*}{ Internal credit } & -1.826921 & 0.6776 \\
\hline & -2.063056 & 0.2600 & & -0.544113 & 0.8737 \\
\hline & -0.796843 & 0.3679 & & 1.939463 & 0.9865 \\
\hline
\end{tabular}


End of Table 3

\begin{tabular}{|c|c|c|c|c|c|}
\hline \multicolumn{3}{|c|}{ Romania } & \multicolumn{3}{|c|}{ Czech Republic } \\
\hline Data series & $\begin{array}{l}\text { Adjusted } \\
t \text { statistics }\end{array}$ & $\mathrm{p}$-value & Data series & $\begin{array}{l}\text { Adjusted } \\
t \text { statistics }\end{array}$ & $\mathrm{p}$-value \\
\hline \multirow{3}{*}{$\begin{array}{l}\text { Internal credit } \\
\text { in first differ- } \\
\text { ence }\end{array}$} & -8.879891 & 0.0000 & \multirow{3}{*}{$\begin{array}{l}\text { Internal credit } \\
\text { in first } \\
\text { difference }\end{array}$} & -3.9528 & 0.01551 \\
\hline & -8.927502 & 0.0000 & & -2.984946 & 0.0428 \\
\hline & -8.951045 & 0.0000 & & -2.564575 & 0.01097 \\
\hline \multirow{3}{*}{$\begin{array}{l}\text { Internal credit } \\
\text { rate }\end{array}$} & -9.122590 & 0.0000 & \multirow{3}{*}{$\begin{array}{l}\text { Exchange rate } \\
\text { in first differ- } \\
\text { ence }\end{array}$} & -7.056189 & 0.000 \\
\hline & -9.036750 & 0.0000 & & -7.062318 & 0.000 \\
\hline & -8.859773 & 0.0000 & & -7.086831 & 0.000 \\
\hline \multirow{3}{*}{ M3 } & -1.737481 & 0.7257 & \multirow{3}{*}{$\begin{array}{l}\text { Interest rate in } \\
\text { first difference }\end{array}$} & -4.71542 & 0.002 \\
\hline & 1.008977 & 0.9964 & & -4.766422 & 0.0003 \\
\hline & 2.525825 & 0.9971 & & -4.679939 & 0.000 \\
\hline \multirow{3}{*}{$\begin{array}{l}\text { M3 in first } \\
\text { level }\end{array}$} & -8.646517 & 0.0000 & \multirow{3}{*}{$\begin{array}{l}\text { M2 in second } \\
\text { difference }\end{array}$} & -3.155717 & 0.005 \\
\hline & -8.356452 & 0.0000 & & -3.063938 & 0.025 \\
\hline & -7.821429 & 0.0000 & & -2.067259 & 0.066 \\
\hline \multirow{3}{*}{ Rate of M3 } & -5.859633 & 0.0001 & \multirow{3}{*}{$\begin{array}{l}\text { M3 in the first } \\
\text { difference }\end{array}$} & -3.177 & 0.049 \\
\hline & -5.233011 & 0.0001 & & -3.1355 & 0.023 \\
\hline & -3.641660 & 0.0006 & & -3.591416 & 0.04567 \\
\hline \multirow{3}{*}{ Rate of M2 } & -7.388108 & 0.0000 & \multirow{3}{*}{ M3 rate } & -3.5488 & 0.0438 \\
\hline & -3.715698 & 0.0006 & & -3.30 & 0.01754 \\
\hline & -2.275543 & 0.0020 & & -3.10 & 0.01071 \\
\hline
\end{tabular}

The Granger causality is checked for these variables with stationary data (see Table 4 for Romania and Table 5 for Czech Republic).

Table 4. Granger causality between economic growth and rate of $M 3$, respectively rate of internal credit in Romania (source: authors' calculations)

\begin{tabular}{|l|c|c|}
\hline \multicolumn{1}{|c|}{ Hypothesis } & F computed & p-value \\
\hline $\begin{array}{l}\text { Rate of internal credit does not cause economic growth in Grang- } \\
\text { er approach }\end{array}$ & 0.25518 & 0.7754 \\
\hline Rate of M3 does not cause economic growth in Granger approach & 7.40730 & 0.0023 \\
\hline $\begin{array}{l}\text { Rate of internal credit does not cause rate of M3 in Granger ap- } \\
\text { proach }\end{array}$ & 10.8914 & 0.0002 \\
\hline Rate of M2 does not cause economic growth in Granger approach & 0.67685 & 0.51125 \\
\hline
\end{tabular}

According to Granger causality test, the rate of $M 3$ in Romania was a cause for economic growth over the period 1995:Q1 - 2015:Q4, while rate of internal credit was an indirect cause through the M3. On the other hand, rate of $M 2$ was not a cause for economic growth in Granger sense. 
Table 5. Granger causality between economic growth and rate of $M 3$, respectively rate of internal credit in Czech Republic (source: authors' calculations)

\begin{tabular}{|l|c|c|}
\hline \multicolumn{1}{|c|}{ Hypothesis } & F computed & p-value \\
\hline $\begin{array}{l}\text { Internal credit variation does not cause economic growth in } \\
\text { Granger approach }\end{array}$ & 1.99034 & 0.14733 \\
\hline Rate of M3 does not cause economic growth in Granger approach & 0.81118 & 0.45009 \\
\hline $\begin{array}{l}\text { Internal credit variation does not cause rate of M3 in Granger } \\
\text { approach }\end{array}$ & 2.04589 & 0.13995 \\
\hline $\begin{array}{l}\text { M2 in double difference does not cause economic growth in } \\
\text { Granger approach }\end{array}$ & 0.66471 & 0.51900 \\
\hline
\end{tabular}

In Czech Republic, there is not a causal relationship between internal credit variation and economic growth or M3 and economic growth.

The cointegration tests (trace and max-eigenvalue tests) indicated the existence of one co-integrating equation at 5\% level of significance. For variables in level an error correction model (ECM) was built in order to study the relationship between variable on long-run and on short-run. According to most of the lag length criteria, the optimal lag equals 2 for Romania and Czech Republic.

The following representation for the ECM model for Romania was proposed:

$$
\begin{aligned}
& D\left(G D P \_S A\right)=C(1) \cdot\left(G D P \_S A(-1)-0.04546668181 \cdot M 2 \_S A(-1)-\right. \\
& \left.0.0002471190338 \cdot C R E D I T \_S A(-1)-22649.82465\right)+C(2) \cdot D\left(G D P \_S A(-1)\right)+ \\
& C(3) \cdot D\left(G D P \_S A(-2)\right)+C(4) \cdot D\left(M 3 \_S A(-1)\right)+C(5) \cdot D\left(M 2 \_S A(-2)\right)+ \\
& C(6) \cdot D\left(C R E D I T \_S A(-1)\right)+C(7) \cdot D\left(C R E D I T \_S A(-2)\right)+C(8) \text {; } \\
& D\left(M 2 \_S A\right)=C(9) \cdot\left(G D P \_S A(-1)-0.04546668181 \cdot M 2 \_S A(-1)-\right. \\
& \left.0.0002471190338 \cdot C R E D I T \_S A(-1)-22649.82465\right)+C(10) \cdot D\left(G D P \_S A(-1)\right)+ \\
& C(11) \cdot D\left(G D P \_S A(-2)\right)+C(12) \cdot D\left(M 2 \_S A(-1)\right)+C(13) \cdot D\left(M 2 \_S A(-2)\right)+ \\
& C(14) \cdot D\left(C R E D I T \_S A(-1)\right)+C(15) \cdot D\left(C R E D I T \_S A(-2)\right)+C(16) \text {; } \\
& D\left(C R E D I T \_S A\right)=C(17) \cdot\left(G D P \_S A(-1)-0.04546668181 \cdot M 2 \_S A(-1)-\right. \\
& \left.0.0002471190338 \cdot C R E D I T \_S A(-1)-22649.82465\right)+C(18) \cdot D\left(G D P \_S A(-1)\right)+ \\
& C(19) \cdot D\left(G D P \_S A(-2)\right)+C(20) \cdot D\left(M 2 \_S A(-1)\right)+C(21) \cdot D\left(M 2 \_S A(-2)\right)+ \\
& C(22) \cdot D\left(C R E D I T \_S A(-1)\right)+C(23) \cdot D\left(C R E D I T \_S A(-2)\right)+C(24) \text {; } \\
& 0.09925276527 \cdot D\left(G D P \_S A(-2)\right)+0.04515480542 \cdot D\left(M 2 \_S A(-1)\right)+ \\
& 0.02327501229 \cdot D\left(M 2 \_S A(-2)\right)-0.000126470858 \cdot D\left(C R E D I T \_S A(-1)\right)+ \\
& \text { 0.0001396672449.D(CREDIT_SA(-2)) - 111.3961102; }
\end{aligned}
$$


$D\left(C R E D I T \_S A\right)=0.1381872051 \cdot\left(G D P \_S A(-1)-0.04546668181 \cdot M 2 \_S A(-1)-\right.$ 0.0002471190338.CREDIT_SA(-1) - 22649.82465 ) + 10.57678667.D(GDP_SA(-1)) -

$10.32404898 \cdot D\left(G D P \_S A(-2)\right)-0.4527590786 \cdot D\left(M 2 \_S A(-1)\right)-$ $0.9736574256 \cdot \mathrm{D}\left(\mathrm{M} 2 \_\mathrm{SA}(-2)\right)-0.01481089373 \cdot \mathrm{D}(\mathrm{CREDIT}$ SSA $(-1))$ -

$$
0.03537148962 \cdot \mathrm{D}(\mathrm{CREDIT} \text { SA }(-2))+7440.457977 \text {, }
$$

where: $C(1), C(2), \ldots, C(24)$ are coefficients in the regressions, $D\left(G D P \_S A\right), D\left(M 2 \_S A\right)$, $D$ (CREDIT_SA) represent seasonally adjusted data series for GDP, money demand and internal credit in first difference.

According to estimations, $C(1)$ has a negative value, fact that shows a long-run causality between GDP, internal credit and M3. In order to establish the existence of the short-run causality, the significance of some of the coefficients is checked $(C(4), C(5), C(6)$ and $C(7))$. The results based on OLS estimation are presented in the Table 6.

Table 6. The significance of the model's coefficients for Romania (source: authors' calculations)

\begin{tabular}{|c|c|c|c|c|}
\hline & Coefficient & Standard Error & $\mathrm{t}$-Statistic & Prob. \\
\hline $\mathrm{C}(1)$ & -0.081120 & 0.038934 & -2.083543 & 0.0384 \\
\hline $\mathrm{C}(2)$ & 0.300893 & 0.115849 & 2.597285 & 0.0100 \\
\hline $\mathrm{C}(3)$ & 0.099253 & 0.118145 & 0.840090 & 0.4018 \\
\hline $\mathrm{C}(4)$ & 0.045155 & 0.019304 & 2.339141 & 0.0202 \\
\hline $\mathrm{C}(5)$ & 0.023275 & 0.019950 & 1.166659 & 0.2446 \\
\hline $\mathrm{C}(6)$ & -0.000126 & 0.001044 & -0.121096 & 0.9037 \\
\hline $\mathrm{C}(7)$ & 0.000140 & 0.001045 & 0.133683 & 0.8938 \\
\hline $\mathrm{C}(8)$ & -111.3961 & 100.9450 & -1.103533 & 0.2710 \\
\hline $\mathrm{C}(9)$ & 1.001340 & 0.228149 & 4.388985 & 0.0000 \\
\hline $\mathrm{C}(10)$ & 0.659402 & 0.678871 & 0.971321 & 0.3325 \\
\hline $\mathrm{C}(11)$ & 0.072008 & 0.692326 & 0.104009 & 0.9173 \\
\hline $\mathrm{C}(12)$ & 0.046384 & 0.113121 & 0.410039 & 0.6822 \\
\hline $\mathrm{C}(13)$ & -0.039480 & 0.116907 & -0.337701 & 0.7359 \\
\hline $\mathrm{C}(14)$ & -0.004367 & 0.006120 & -0.713597 & 0.4762 \\
\hline $\mathrm{C}(15)$ & -0.000776 & 0.006122 & -0.126682 & 0.8993 \\
\hline$C(16)$ & 3164.617 & 591.5330 & 5.349857 & 0.0000 \\
\hline $\mathrm{C}(17)$ & 0.138187 & 4.397549 & 0.031424 & 0.9750 \\
\hline $\mathrm{C}(18)$ & 10.57679 & 13.08520 & 0.808301 & 0.4198 \\
\hline $\mathrm{C}(19)$ & -10.32405 & 13.34455 & -0.773653 & 0.4400 \\
\hline $\mathrm{C}(20)$ & -0.452759 & 2.180393 & -0.207650 & 0.8357 \\
\hline $\mathrm{C}(21)$ & -0.973657 & 2.253374 & -0.432089 & 0.6661 \\
\hline $\mathrm{C}(22)$ & -0.014811 & 0.117964 & -0.125554 & 0.9002 \\
\hline $\mathrm{C}(23)$ & -0.035371 & 0.118006 & -0.299743 & 0.7647 \\
\hline $\mathrm{C}(24)$ & 7440.458 & 11401.76 & 0.652571 & 0.5147 \\
\hline
\end{tabular}


Only $C(4)$ significantly differs from 0 , which indicates that there is also a short-run causality from $M 3$ to GDP in Romania.

All the results regarding the estimation of the ECM model are presented in Appendix 1 . The errors are homoscedastic at $5 \%$ level of significance, the chi-square statistic being 105.4408 (associated p-value is 0.0569 ). Moreover, the errors are not serial correlated till a lag equaled to 12 at $5 \%$ level of significance.

According to variance decomposition for seasonally adjusted GDP in Table 7, in the first period after a shock in economy, the changes in GDP are caused only by that shock. After two periods, only $97.01 \%$ of the variation in GDP is due to changes in GDP, $2.98 \%$ of the variation being due to changes in money demand $M 2$. The influence of $M 2$ increases in time, arriving to around $12.57 \%$ at the $10^{\text {th }}$ lag.

Table 7. Variance decomposition of gross domestic product in Romania (source: authors' calculations)

\begin{tabular}{|c|c|c|c|c|}
\hline Period & S.E. & GDP_SA & M2_SA & CREDIT_SA \\
\hline 1 & 426.5012 & 100.0000 & 0.000000 & 0.000000 \\
\hline 2 & 698.2645 & 97.01104 & 2.983764 & 0.005201 \\
\hline 3 & 956.0067 & 93.38813 & 6.599879 & 0.011986 \\
\hline 4 & 1182.363 & 91.33128 & 8.638524 & 0.030194 \\
\hline 5 & 1381.869 & 90.02742 & 9.928052 & 0.044524 \\
\hline 6 & 1559.770 & 89.13294 & 10.81268 & 0.054379 \\
\hline 7 & 1719.995 & 88.49293 & 11.44548 & 0.061592 \\
\hline 8 & 1865.788 & 88.01629 & 11.91673 & 0.066980 \\
\hline 9 & 1999.728 & 87.64864 & 12.28029 & 0.071072 \\
\hline 10 & 2123.822 & 87.35639 & 12.56937 & 0.074248 \\
\hline
\end{tabular}

Note: S.E. is standard error.

The following representation for the ECM model for Czech Republic was given:

$$
\begin{gathered}
D\left(G D P \_S A\right)=A(1,1) \cdot\left(B(1,1) \cdot G D P \_S A(-1)+B(1,2) \cdot M 3 \_S A(-1)+B(1,3) \cdot C R E D I T \_S A(-1)+\right. \\
B(1,4))+C(1,1) \cdot D\left(G D P \_S A(-1)\right)+C(1,2) \cdot D\left(G D P \_S A(-2)\right)+C(1,3) \cdot D\left(M 3 \_S A(-1)\right)+ \\
C(1,4) \cdot D\left(M 3 \_S A(-2)\right)+C(1,5) \cdot D\left(C R E D I T \_S A(-1)\right)+C(1,6) \cdot D\left(C R E D I T \_S A(-2)\right)+C(1,7) ;(13) \\
D\left(M 3 \_S A\right)=A(2,1) \cdot\left(B(1,1) \cdot G D P \_S A(-1)+B(1,2) \cdot M 3 \_S A(-1)+B(1,3) \cdot C R E D I T \_S A(-1)+\right. \\
B(1,4))+C(2,1) \cdot D\left(G D P \_S A(-1)\right)+C(2,2) \cdot D\left(G D P \_S A(-2)\right)+C(2,3) \cdot D\left(M 3 \_S A(-1)\right)+ \\
C(2,4) \cdot D\left(M 3 \_S A(-2)\right)+C(2,5) \cdot D\left(C R E D I T \_S A(-1)\right)+C(2,6) \cdot D\left(C R E D I T \_S A(-2)\right)+C(2,7) ;(14) \\
D\left(C R E D I T \_S A\right)=A(3,1) \cdot\left(B(1,1) \cdot G D P \_S A(-1)+B(1,2) \cdot M 3 \_S A(-1)+B(1,3) \cdot C R E D I T \_S A(-1)+\right. \\
B(1,4))+C(3,1) \cdot D\left(G D P \_S A(-1)\right)+C(3,2) \cdot D\left(G D P \_S A(-2)\right)+C(3,3) \cdot D\left(M 3 \_S A(-1)\right)+ \\
C(3,4) \cdot D\left(M 3 \_S A(-2)\right)+C(3,5) \cdot D\left(C R E D I T \_S A(-1)\right)+C(3,6) \cdot D\left(C R E D I T \_S A(-2)\right)+C(3,7) \cdot(15)
\end{gathered}
$$


VAR Model - Substituted Coefficients:

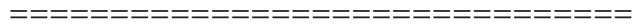

$$
\begin{aligned}
& D\left(G D P \_S A\right)=0.06619860718 \cdot\left(G D P \_S A(-1)+0.0001106598014 \cdot M 3 \_S A(-1)-\right. \\
& \left.0.0001446134031 \cdot C R E D I T \_S A(-1)-122.4448315\right)-0.002524380149 \cdot D\left(G D P \_S A(-1)\right)- \\
& 0.08128147219 \cdot D\left(G D P \_S A(-2)\right)-2.269653903 e-05 \cdot D\left(M 3 \_S A(-1)\right)- \\
& 3.751938115 e-06 \cdot D\left(M 3 \_S A(-2)\right)+2.794035506 e-05 \cdot D\left(C R E D I T \_S A(-1)\right)- \\
& 1.108711242 e-05 \cdot D\left(C R E D I T \_S A(-2)\right)+1.188112996 ;
\end{aligned}
$$

According to estimations for Czech Republic, $C(1)$ has a positive value, fact that does not show a long-run causality between $G D P$, internal credit and $M 3$. The coefficients $C(4), C(5)$, $C(6)$ and $C(7)$ are not statistically significant and a short-run causality was not identified.

In the next stage, using the data for both countries, a dynamic panel data model was built to explain the GDP using the monetary variables ( $M 3$ and internal credit) as we can see in Table 8.

Table 8. Dynamic panel model with Arrelano-Bover/Blundell-Bond estimator (source: authors' calculations)

\begin{tabular}{|l|c|c|c|c|}
\hline \multicolumn{1}{|c|}{ Explanatory variable } & Coefficient & Standard error & $Z$ & $P>|z|$ \\
\hline$G D P$ in the previous period & 0.6693275 & 0.0532114 & 12.58 & 0.000 \\
\hline Internal credit & -6.234597 & 1.479727 & -4.21 & 0.000 \\
\hline$M 3$ & 4.532594 & 1.071852 & 4.23 & 0.000 \\
\hline Constant & 828591.5 & 283018.1 & 2.93 & 0.003 \\
\hline
\end{tabular}

Note: $Z$ is the computed statistic and $P$ is the associated p-value.

The estimations' results (Table 8) showed a positive relationship between GDP in the current period and GDP in the previous period. An increase in GDP in the previous period by one unit will generate an increase in the current GDP by 0.669 units. Contrary to expectations, the internal credit was negatively correlated to GDP. As Leitão showed that there is not any consensus in literature regarding to support that domestic credit stimulates the economic growth (Leitão 2013). Leitão observed a positive correlation between GDP and credit using a dynamic panel data for BRIC countries (Brazil, Russia, China, India) and for the European Union member states during the period 1980-2006 (Leitão 2010). Our empirical results are consistent with the findings of Levine and of Hassan, Sanchez 
and Yu, Korauš et al. who showed a negative impact of domestic credit on GDP (Levine 1997; Sanchez, Yu 2011; Korauš et al. 2017). In this case, the internal credit discouraged the investment and saving that might support the economic growth of a country. Other authors showed that a system using high taxes discourages the economic growth of that country (Padovano, Galli 2002; Koch et al. 2005; Lee, Gordon 2005). The fiscal policy could be used as control measure opportunity to adjust inflation or government spending. As expected, $M 3$ had a positive influence on GDP. At each increase in $M 3$ by 1 unit, the GDP increases, in average, by almost 4.53 units.

However, it should be noted that the period from 2002 to 2016 was characterized in both countries by phases of economic growth and recession. The business cycle phases could affect the relationship between GDP and monetary variables.

\section{Conclusions}

The relationship between output and money has been the subject of many studies in the last years. The results depend on the type of economy. In this research, we chose two countries that experience a different economic development after the collapse of communist regime. Using the VECM framework, we showed that in Romania and in Czech Republic there was a long-run relationship between GDP, internal credit and $M 3$ and a short-run relationship only from $M 3$ to output. The rate of $M 3$ was a cause of economic growth in Romania. However, it was not confirmed for Czech Republic. Alternative methods for studying the relationship money-output could be Bayesian VAR models or complex approaches based on DSGE models.

The novelty of this research is given by the comparative analysis of this relationship for two countries with different economic evolutions in the transition from planned economy to market economy. The obtained interesting results contradict the money neutrality hypothesis in post-transformation Central European economies. We brought evidence against money neutrality based on two different econometric approaches: a time series approach for VEC models and a panel data approach using dynamic models. Contrary to economic theory, the internal credit was negatively correlated to GDP. In our case, the internal credit discouraged the investment and saving that might support the economic growth of a country.

In that context as expected, the dynamic panel approach indicated that M3 had a positive impact on output, but the internal credit had a negative influence, as it could discourage investment and saving.

As a result, the provided research can be treated as a voice against the hypothesis of money neutrality in post-transformation countries. The practical implications of these results are related to the policies design. The fiscal policy could be used as control measure opportunity to adjust inflation or government spending.

In the future, this research might be extended in regard to methodological perspective, for example by introducing DSGE models. The additional direction of future research can be seen in the need for comparisons of the results with those for other countries in the Central and Eastern Europe. 


\section{References}

Albuquerque, B.; Baumann, U.; Seitz, F. 2016. What does money and credit tell us about real activity in the United States?, The North American Journal of Economics and Finance 37: 328-347. https://doi.org/10.1016/j.najef.2016.05.011

Asongu, S. 2016. New empirics of monetary policy dynamics: evidence from the CFA franc zones, African Journal of Economic and Management Studies 7(2): 164-204. https://doi.org/10.1108/AJEMS-11-2012-0079

Bae, S. K.; Jensen, M. J.; Murdock, S. G. 2005. Long-run neutrality in a fractionally integrated model, Journal of Macroeconomics 27(2): 257-274. https://doi.org/10.1016/j.jmacro.2003.11.019

Belongia, M. T.; Ireland, P. N. 2016. The evolution of U.S. monetary policy: 2000-2007, Journal of Economic Dynamics and Control 73: 78-93. https://doi.org/10.3386/w22693

Brózda, D. 2016. Transmission mechanism of the Federal Reserve system's monetary policy in the conditions of zero bound on nominal interest rates, Equilibrium. Quarterly Journal of Economics and Economic Policy 11(4): 751-767. https://doi.org/10.12775/EQUIL.2016.034

Chen, S. W. 2007. Evidence of the long-run neutrality of money: the case of South Korea and Taiwan, Economics Bulletin 3(64): 1-18.

Clarida, R.; Gali, J.; Gertler, M. 2000. Monetary policy rules and macroeconomic stability: evidence and some theory, Quarterly Journal of Economics 115: 147-180. https://doi.org/10.1162/003355300554692

Duca, J. V.; VanHoose, D. D. 2004. Recent developments in understanding the demand for money, Journal of Economics and Business 56: 247-272. https://doi.org/10.1016/j.jeconbus.2004.01.001

Fałdziński, M.; Balcerzak, A. P.; Meluzín, T.; Pietrzak, M. B.; Zinecker, M. 2016. Cointegration of interdependencies among capital markets of chosen Visegrad countries and Germany, in $34^{\text {th }}$ International Conference Mathematical Methods in Economics MME 2016, 6-9 September 2016, Liberec, Czech Republic.

Fisher, M. E.; Seater, J. J. 1993. Long-run neutrality and superneutrality in an ARIMA framework, American Economic Review 83(3): 402-415.

Gefang, D. 2012. Money-output causality revisited - a Bayesian logistic smooth transition VECM perspective, Oxford Bulletin of Economics and Statistics 74(1): 131-151. https://doi.org/10.1111/j.1468-0084.2011.00652.x

Hassan, M.; Sanchez, K.; Yu, S. J. 2011. Financial development and economic growth: New evidence from panel data, The Quarterly Review of Economic and Finance 51: 88-104. https://doi.org/10.1016/j.qref.2010.09.001

Hill, J. B. 2007. Efficient tests of long-run causation in trivariate VAR processes with a rolling window study of the money-income relationship, Journal of Applied Econometrics 22: 747-765. https://doi.org/10.1002/jae.925

Hiscock, R.; Handa, J. 2013. Long-run neutrality and superneutrality of money in South American economies, Applied Financial Economics 23(9): 739-747. https://doi.org/10.1080/09603107.2012.744132

Issaoui, F.; Boufateh, T.; Guesmi, M. 2015. Money neutrality: rethinking the myth, Panoecomicus 62(3): 287-320. https://doi.org/10.2298/PAN1503287I

Janus, J. 2016. The transmission mechanism of unconventional monetary policy, Oeconomia Copernicana 7(1): 7-21. https://doi.org/10.12775/OeC.2016.001

Jędrzejowska Schiffauer, I.; Schiffauer, P. 2016. European Central Bank's OMT decision: still within the framework of the monetary policy?, Journal of International Studies 9(2): 195-206. https://doi.org/10.14254/2071-8330.2016/9-2/15 
King, R. G.; Watson, M. W. 1997. Testing long-run neutrality. Federal Reserve Bank of Richmond, Economic Quarterly 83(3): 69-101.

Koch, S.; Schoeman, N.; Tonder, J. 2005. Economic growth and the structure of taxes in South Africa: 1960-2002, The South African Journal of Economics 73(2): 190-210. https://doi.org/10.1111/j.1813-6982.2005.00013.x

Korauš, A.; Simionescu, M.; Bilan, Y.; Schönfeld, J. 2017. The impact of monetary variables on the economic growth and sustainable development: case of selected countries, Journal of Security and Sustainability Issues 6(3): 383-390. https://doi.org/10.9770/jssi.2017.6.3(5)

Lakic, S.; Draskovic, M. 2015. Implications of institutional dispositions of neoliberalism, Montenegrin Journal of Economics 11(2): 113-121. https://doi.org/10.14254/1800-5845.2015/11-2/7

Lee, J. 2012. Nonparametric testing for long-run neutrality with applications to US money and output data, Computational Economics 40(2): 183-202. https://doi.org/10.1007/s10614-011-9270-2

Lee, Y.; Gordon, R. H. 2005. Tax structure and economic growth, Journal of Public Economics 89(5-6): 1027-1043. https://doi.org/10.1016/j.jpubeco.2004.07.002

Leitão, N. C. 2010. Financial development and economic growth: A panel data approach, Theoretical and Applied Economics 5(511): 15-24.

Leitão, N. C. 2013. Financial management and economic growth: The European countries experience, Economia. Seria Management 4: 261-268.

Levine, R. 1997. Financial development and economic growth: Views and agenda, Journal of Economic Literature 35: 688-726.

Li, H.; Zhong, W.; Park, S. Y. 2016. Generalized cross-spectral test for nonlinear Granger causality with applications to money-output and price-volume relations, Economic Modelling 52: 661-671. https://doi.org/10.1016/j.econmod.2015.09.037

Lucas, R. E. 1980. Two illustrations of the quantity theory of money, American Economic Review 70(5): 1005-1014.

Nelson, E. 2003. The future of monetary aggregates in monetary policy analysis, Journal of Monetary Economics 50: 1029-1059. https://doi.org/10.1016/S0304-3932(03)00063-1

Padovano, F.; Galli, E. 2002. Comparing the growth effects of marginal vs. average tax rates and progressivity, Europäische Zeitschrift für politische Ökonomie 18(3): 529-544.

Palankai, T. 2015. The introduction of the euro and central Europe, Economics \& Sociology 8(2): 51-61. https://doi.org/10.14254/2071-789X.2015/8-2/5

Pietrzak, M. B.; Fałdziński, M.; Balcerzak, A. P.; Meluzín, T.; Zinecker, M. 2017. Short-term shocks and long-term relationships of interdependencies among central european capital markets, Economics \& Sociology 10(1): 61-77. https://doi.org/10.14254/2071-789X.2017/10-1/5

Saatcioglu, C.; Korap, L. 2009. The search for co-integration between money, prices and income: low frequency evidence from the Turkish economy, Panoeconomicus 56(1): 55-72. https://doi.org/10.2298/PAN0901055S

Sargent, T. J.; Surico, P. 2011. Two illustrations of the quantity theory of money: breakdowns and revivals, American Economic Review 101(1): 109-128. https://doi.org/10.1257/aer.101.1.109

Simionescu, M. 2014. The assessment of parameters' uncertainty in a vector error correction model for Romania, Romanian Journal of Economics 37(2): 124-134.

Simionescu, M.; Popescu, J.; Firescu, V. 2017. The relationship between gross domestic product and monetary variables in Romania. A Bayesian approach, Economic research-Ekonomska istraživanja 30(1): 464-476. https://doi.org/10.1080/1331677X.2017.1305798

Sims, C. 1972. 'Money, income and causality', American Economic Review 62: 540-552. 
Sims, C. A.; Zha, T. 2006. Were there regime switches in U.S. monetary policy?, American Economic Review 96: 54-81. https://doi.org/10.1257/000282806776157678

Stock, J. H.; Watson, M. W. 1989. Interpreting the evidence on money-income causality, Journal of Econometrics 40: 161-181. https://doi.org/10.1016/0304-4076(89)90035-3

Svitálková, Z. 2014. Comparison and evaluation of bank efficiency in Austria and the Czech Republic, Journal of Competitiveness 6(2): 15-29. https://doi.org/10.7441/joc.2014.02.02

Taylor, J. B.1999. Monetary policy rules. Chicago: University of Chicago Press, 15-18. https://doi.org/10.7208/chicago/9780226791265.001.0001

Telatar, E.; Cavusoglu, T. 2005. Long-run monetary neutrality: Evidence from high inflation countries, Ekonomicky Casopis 53(9): 895-910.

Urbanovský, T. 2016. Interconnection of interest rate, price level, money supply and real GDP: The case of the Czech Republic, Procedia-Social and Behavioral Sciences 220: 531-540. https://doi.org/10.1016/j.sbspro.2016.05.529

Wang, X.; Zheng, T.; Zhu, Y. 2014. Money-output Granger causal dynamics in China, Economic Modelling 43: 192-200. https://doi.org/10.1016/j.econmod.2014.08.004

Ylldırım, T. 2015. Did the euro trigger the European dept crises?, Journal of International Studies 8(2): 43-51. https://doi.org/10.14254/2071-8330.2015/8-2/4 


\section{Appendix 1}

Table A1. Lag length criteria in the case of the model for Romania (source: authors' calculations)

\begin{tabular}{|c|c|c|c|c|c|c|}
\hline Lag & LogL & LR & FPE & AIC & SC & HQ \\
\hline 0 & -2655.628 & NA & $1.96 \mathrm{E}+26$ & 69.05527 & 69.14659 & 69.09180 \\
\hline 1 & -2215.812 & 833.9363 & $2.71 \mathrm{E}+21$ & 57.86525 & $58.23052^{\star}$ & 58.01136 \\
\hline 2 & -2201.600 & $25.84109^{\star}$ & $2.37 \mathrm{E}+21^{\star}$ & $57.72986^{*}$ & 58.36908 & $57.98554^{*}$ \\
\hline 3 & -2199.898 & 2.960686 & $2.87 \mathrm{E}+21$ & 57.91944 & 58.83261 & 58.28470 \\
\hline 4 & -2194.340 & 9.239892 & $3.16 \mathrm{E}+21$ & 58.00883 & 59.19595 & 58.48367 \\
\hline 5 & -2187.274 & 11.19472 & $3.35 \mathrm{E}+21$ & 58.05908 & 59.52015 & 58.64349 \\
\hline 6 & -2180.887 & 9.622257 & $3.63 \mathrm{E}+21$ & 58.12694 & 59.86197 & 58.82094 \\
\hline 7 & -2177.258 & 5.185088 & $4.25 \mathrm{E}+21$ & 58.26643 & 60.27541 & 59.07001 \\
\hline
\end{tabular}

* indicates lag order selected by the criterion

LR: sequential modified LR test statistic (each test at 5\% level)

FPE: Final prediction error

AIC: Akaike information criterion

SC: Schwarz information criterion

HQ: Hannan-Quinn information criterion

Table A2. Lag length criteria in the case of the model for Czech Republic (source: authors' calculations)

\begin{tabular}{|c|c|c|c|c|c|c|}
\hline Lag & LogL & LR & FPE & AIC & SC & HQ \\
\hline 0 & -1588.791 & NA & $2.45 \mathrm{E}+22$ & 60.06760 & 60.17912 & 60.11048 \\
\hline 1 & -1234.682 & 654.7680 & $5.42 \mathrm{E}+16$ & 47.04461 & $47.49071^{\star}$ & 47.21616 \\
\hline 2 & -1220.293 & 24.97676 & $4.44 \mathrm{E}+16^{\star}$ & $46.84126^{\star}$ & 47.62194 & $47.14147^{\star}$ \\
\hline 3 & -1214.841 & 8.846478 & $5.12 \mathrm{E}+16$ & 46.97515 & 48.09041 & 47.40402 \\
\hline 4 & -1211.439 & 5.135090 & $6.44 \mathrm{E}+16$ & 47.18639 & 48.63623 & 47.74393 \\
\hline 5 & -1198.522 & $18.03551^{\star}$ & $5.71 \mathrm{E}+16$ & 47.03857 & 48.82299 & 47.72477 \\
\hline
\end{tabular}

* indicates lag order selected by the criterion

LR: sequential modified LR test statistic (each test at $5 \%$ level)

FPE: Final prediction error

AIC: Akaike information criterion

SC: Schwarz information criterion

HQ: Hannan-Quinn information criterion

Table A3. Vector error correction estimates (source: authors' calculations)

Sample(adjusted): 1995:4 2015:4

Included observations: 81 after adjusting endpoints

Standard errors in ( ) \& t-statistics in [ ]

\begin{tabular}{|l|c|l|l|}
\hline Cointegrating Eq: & CointEq1 & & \\
\hline GDP_SA(-1) & 1.000000 & & \\
\hline & & & \\
\hline
\end{tabular}


Continued Table A3

\begin{tabular}{|c|c|c|c|}
\hline \multirow[t]{3}{*}{ M2_SA(-1) } & -0.045467 & & \\
\hline & $(0.00347)$ & & \\
\hline & {$[-13.0978]$} & & \\
\hline \multirow[t]{3}{*}{ CREDIT_SA(-1) } & -0.000247 & & \\
\hline & $(0.00278)$ & & \\
\hline & {$[-0.08878]$} & & \\
\hline $\mathrm{C}$ & -22649.82 & & \\
\hline Error Correction: & D(GDP_SA) & D(M2_SA) & D(CREDIT_SA) \\
\hline \multirow[t]{3}{*}{ CointEq1 } & -0.081120 & 1.001340 & 0.138187 \\
\hline & $(0.03893)$ & $(0.22815)$ & $(4.39755)$ \\
\hline & {$[-2.08354]$} & [ 4.38898] & {$[0.03142]$} \\
\hline \multirow[t]{3}{*}{ D(GDP_SA(-1)) } & 0.300893 & 0.659402 & 10.57679 \\
\hline & $(0.11585)$ & $(0.67887)$ & $(13.0852)$ \\
\hline & [ 2.59728] & {$[0.97132]$} & {$[0.80830]$} \\
\hline \multirow[t]{3}{*}{ D(GDP_SA(-2)) } & 0.099253 & 0.072008 & -10.32405 \\
\hline & $(0.11815)$ & $(0.69233)$ & $(13.3445)$ \\
\hline & [ 0.84009] & {$[0.10401]$} & {$[-0.77365]$} \\
\hline \multirow[t]{3}{*}{$\mathrm{D}\left(\mathrm{M} 2 \_\mathrm{SA}(-1)\right)$} & 0.045155 & 0.046384 & -0.452759 \\
\hline & $(0.01930)$ & $(0.11312)$ & $(2.18039)$ \\
\hline & [2.33914] & {$[0.41004]$} & {$[-0.20765]$} \\
\hline \multirow[t]{3}{*}{$\mathrm{D}\left(\mathrm{M} 2 \_\mathrm{SA}(-2)\right)$} & 0.023275 & -0.039480 & -0.973657 \\
\hline & $(0.01995)$ & $(0.11691)$ & $(2.25337)$ \\
\hline & {$[1.16666]$} & {$[-0.33770]$} & {$[-0.43209]$} \\
\hline \multirow[t]{3}{*}{ D(CREDIT_SA(-1)) } & -0.000126 & -0.004367 & -0.014811 \\
\hline & $(0.00104)$ & $(0.00612)$ & $(0.11796)$ \\
\hline & {$[-0.12110]$} & {$[-0.71360]$} & {$[-0.12555]$} \\
\hline \multirow[t]{3}{*}{ D(CREDIT_SA(-2)) } & 0.000140 & -0.000776 & -0.035371 \\
\hline & $(0.00104)$ & $(0.00612)$ & $(0.11801)$ \\
\hline & {$[0.13368]$} & {$[-0.12668]$} & {$[-0.29974]$} \\
\hline \multirow[t]{3}{*}{$\mathrm{C}$} & -111.3961 & 3164.617 & 7440.458 \\
\hline & $(100.945)$ & (591.533) & (11401.8) \\
\hline & {$[-1.10353]$} & [ 5.34986] & [ 0.65257] \\
\hline R-squared & 0.198846 & 0.430752 & 0.021436 \\
\hline Adj. R-squared & 0.122023 & 0.376167 & -0.072399 \\
\hline
\end{tabular}


End of Table A3

\begin{tabular}{|l|r|r|r|}
\hline Sum sq. resids & 13278936 & $4.56 \mathrm{E}+08$ & $1.69 \mathrm{E}+11$ \\
\hline S.E. equation & 426.5012 & 2499.277 & 48173.41 \\
\hline F-statistic & 2.588361 & 7.891344 & 0.228442 \\
\hline Log likelihood & -601.2273 & -744.4467 & -984.1100 \\
\hline Akaike AIC & 15.04265 & 18.57893 & 24.49654 \\
\hline Schwarz SC & 15.27914 & 18.81542 & 24.73303 \\
\hline Mean dependent & 179.2762 & 3303.807 & 2787.107 \\
\hline S.D. dependent & 455.1752 & 3164.319 & 46518.87 \\
\hline Determinant Residual Covariance & $2.47 \mathrm{E}+21$ & \\
\hline Log Likelihood & -2327.202 & \\
\hline Log Likelihood (d.f. adjusted) & -2339.837 & \\
\hline Akaike Information Criteria & 58.44043 & \\
\hline Schwarz Criteria & 59.23857 & \\
\hline
\end{tabular}

Table A4. VEC Residual serial correlation LM tests (source: authors' calculations)

H0: no serial correlation at lag order $\mathrm{h}$

Sample: 1995:1 2015:4

Included observations: 81

\begin{tabular}{|c|c|c|}
\hline Lags & LM-Stat & Prob \\
\hline 1 & 14.78915 & 0.0969 \\
\hline 2 & 7.454498 & 0.5899 \\
\hline 3 & 7.084988 & 0.6283 \\
\hline 4 & 7.713913 & 0.5632 \\
\hline 5 & 6.419858 & 0.6973 \\
\hline 6 & 3.354944 & 0.9485 \\
\hline 7 & 6.797756 & 0.6582 \\
\hline 8 & 6.233630 & 0.7163 \\
\hline 9 & 2.002111 & 0.9914 \\
\hline 10 & 7.292665 & 0.6067 \\
\hline 11 & 4.998815 & 0.8344 \\
\hline 12 & 10.73309 & 0.2944 \\
\hline \multicolumn{2}{|c|}{ Probs from chi-square with 9 df. } \\
\hline
\end{tabular}


Table A5. VEC residual heteroskedasticity tests (source: authors' calculations)

Sample: 1995:1 2015:4

Included observations: 81

\begin{tabular}{|c|c|c|c|}
\hline \multicolumn{5}{|c|}{ Joint test: } \\
\hline & & & \\
\hline Chi-sq & $\mathrm{df}$ & Prob. & \\
\hline & & & \\
\hline 105.4408 & 84 & 0.0569 & \\
\hline
\end{tabular}

Table A6. Unrestricted cointegration rank tests (source: authors' computations)

\begin{tabular}{|c|c|c|c|c|}
\hline Hypothesized & & Trace & 5 Percent & 1 Percent \\
\hline No. of CE(s) & Eigenvalue & Statistic & Critical Value & Critical Value \\
\hline None ${ }^{\star}$ & 0.275770 & 32.94760 & 29.68 & 35.65 \\
\hline At most 1 & 0.080147 & 6.813286 & 15.41 & 20.04 \\
\hline At most 2 & 0.000573 & 0.046443 & 3.76 & 6.65 \\
\hline \multicolumn{5}{|c|}{$\begin{array}{l}\left.{ }^{*}{ }^{* *}\right) \text { denotes rejection of the hypothesis at the } 5 \%(1 \%) \text { level } \\
\text { Trace test indicates } 1 \text { cointegrating equation(s) at the } 5 \% \text { level } \\
\text { Trace test indicates no cointegration at the } 1 \% \text { level }\end{array}$} \\
\hline Hypothesized & & Max-Eigen & 5 Percent & 1 Percent \\
\hline No. of CE(s) & Eigenvalue & Statistic & Critical Value & Critical Value \\
\hline None ${ }^{* *}$ & 0.275770 & 26.13432 & 20.97 & 25.52 \\
\hline At most 1 & 0.080147 & 6.766842 & 14.07 & 18.63 \\
\hline At most 2 & 0.000573 & 0.046443 & 3.76 & 6.65 \\
\hline
\end{tabular}

